\title{
Determination of Antimicrobial Resistance and Resistant Genes in Acinetobacter baumannii from Human Clinical Samples
}

F Khamesipour ${ }^{1,2}, \mathrm{H} \mathrm{Momtaz}^{3}, \mathrm{M} \mathrm{Tavakol}^{4}$, B Awodile ${ }^{5}$

\begin{abstract}
Objective: The aim of this study is to determine the prevalence, antimicrobial resistance and various resistance genes in Acinetobacter baumannii (A baumannii) from human clinical specimens at the payambaran and Baqiyatallah Hospitals in the city of Tehran, Iran, over a period of six months (September 2012 to March 2013).

Methods: A total of 500 samples including blood, phlegm, urine, cerebrospinal fluid (CSF) and pus were collected from patients on admission in these hospitals. A baumannii was identified by using standard microbiological procedures and conventional polymerase chain reaction (PCR) technique. Antimicrobial susceptibility test was performed according to clinical and laboratory standard institute (CLSI) guidelines using Kirby-Bauer disc diffusion technique, while different resistance genes were detected using PCR method.

Results: A total of 121 A baumannii was detected out of 500 samples, representing $24.20 \%$ period prevalence. A baumannii was detected from all the sample groups, but a higher prevalence was observed in the blood (43.87\%) and phlegm (24.11\%). Antibiotic resistance profile showed higher resistance of A baumannii to tetracycline (90.90\%), trimethoprim (61.98\%) and cotrimoxazole $(51.23 \%)$, followed by aminoglycosides (9.91-31.40\%). Relatively low resistance was observed to cephalosporins (16.52-20.66\%), quinolones (6.61-9.91\%) and macrolides (8.26-14.04\%), while the lowest resistance was observed to carbapenems (3.3-5.78\%), chloramphenicol and nitrofurantoin. Highest detection for resistant genes was observed for tetA (58.67\%), aac (3)-IV (56.19\%), sul1 (55.37\%) and dfrAl (48.76\%). Relatively low detection was observed for aad Al, bla-genes (SHV, CTX-M, OXA-like, VIM, SIM and IMP) and lowest detection was observed for cat 1 and cmlA, while no qnr gene was detected.

Conclusions: Multidrug-resistant Acinetobacter infections are posing an increasing threat to the population in these communities. Carbapenems provide an effective option against infections caused by resistant A baumannii.
\end{abstract}

Keywords: Acinetobacter baumannii, antimicrobial resistance, human clinical samples, resistant genes

\section{Determinación de la Resistencia Antimicrobiana y los Genes Resistentes Frente a la Acinetobacter baumannii de Muestras Clínicas Humanas}

\author{
F Khamesipour ${ }^{1,2}, \mathrm{H} \mathrm{Momtaz}^{3}$, M Tavakol ${ }^{4}$, B Awosile ${ }^{5}$
}

\begin{abstract}
RESUMEN
Objetivo: El objetivo de este estudio es determinar la prevalencia, resistencia antimicrobiana, y varios genes de resistencia frente a la Acinetobacter baumannii (A baumannii) de muestras clínicas humanas en el hospital de Payambaran y el de Baqiyatallah en la ciudad de Teherán, Irán, durante un periodo de seis meses (de septiembre de 2012 a marzo de 2013).

Métodos: Se recogieron un total de 500 muestras, incluyendo muestras de sangre, flema, orina, líquido cefalorraquídeo (LCR), y pus de los pacientes al ingresar en estos hospitales. La A baumannii fue identificada mediante procedimientos microbiológicos estándar y la técnica de reacción en cadena de la polimerasa (RCP) convencional. La prueba de susceptibilidad antimicrobiana se realizó según las guías
\end{abstract}

From: ${ }^{1}$ Health Policy Research Center, Institute of Health, Shiraz University of Medical Sciences, Shiraz, Iran, ${ }^{2}$ Cellular and Molecular Research Center, Sabzevar University of Medical Sciences, Sabzevar, Iran, ${ }^{3}$ Department of Microbiology, Faculty of Veterinary Medicine, Shahrekord Branch, Islamic Azad University, Shahrekord, Iran, ${ }^{4}$ Department of Biology, Ashkzar Branch, Islamic Azad University, Ashkzar, Iran and ${ }^{5}$ Department of Health
Management, University of Prince Edward Island, Charlottetown, PE C1A 4P3, Canada.

Correspondence: Dr H Momtaz, Department of Microbiology, Faculty of Veterinary Medicine, Shahrekord Branch, Islamic Azad University, PO Box 166, Shahrekord, Iran. Email: hamomtaz@iaushk.ac.ir; hamomtaz@yahoo.com 
de Clinical and Laboratory Standards Institute (CLSI), usando la técnica de difusión en disco de KirbyBauer, mientras que los diferentes genes de resistencia fueron detectados usando el método de RCP.

Resultados: Un total de 121 A. baumannii fue detectado en las 500 muestras, representando un $24.20 \%$ de prevalencia en el periodo. A. baumannii fue detectada en todos los grupos muestrarios, pero la prevalencia más alta se observó en la sangre (43.87\%) y la flema (24.11\%). El perfil de resistencia a los antibióticos mostró mayor resistencia de A. baumannii a la tetraciclina (90.90\%), la trimetoprima (61.98\%) y el cotrimoxazol (51.23\%), seguido por los aminoglucósidos (9,91-31.40\%). Una resistencia relativamente baja se observó en las cefalosporinas (16.52-20.66\%), las quinolonas (6.61-9.91\%) y los macrólidos (8.26-14.04\%), mientras que la resistencia más baja se observó en las carbapenemas (3.3-5,78\%), el cloranfenicol y la nitrofurantoína. La mayor detección de genes resistentes se observó en tetA (58.67\%), aac 3-IV (56.19\%), sull (55.37\%) y dfrAl (48.76\%). Una detección relativamente baja se observó en aad Al, genes bla (SHV, CTX-M, tipo OXA, VIM, SIM e IMP), en tanto que la detección más baja se observó en cat1 y cmlA, no detectándose ningún gen qnr.

Conclusiones: Las infecciones por Acinetobacter multirresistentes representan una creciente amenaza para la población de estas comunidades. Las carbapenemas proveen una opción efectiva contra las infecciones causadas por A. baumannii resistente.

Palabras claves: Acinetobacter baumannii, resistencia a los antimicrobianos, muestras clínicas humanas, genes resistentes

West Indian Med J 2017; 66 (1): 57

\section{INTRODUCTION}

Acinetobacter baumanii (A baumannii) is a gram-negative, pleomorphic aerobic species commonly isolated from many sources in the environment, including drinking and static water, soil, sewage, food, and the skin of humans and animals. It is usually considered to be an opportunistic pathogen especially in hospitals and healthcare units (1-3). A baumannii is a major species, contributing to about $80 \%$ of all Acinetobacter hospital-acquired infections (4).

It is often difficult to distinguish between infection and colonization with A baumannii (5). There is considerable controversy over whether infections caused by this organism leads to unfavourable outcomes; however, it is believed by some clinicians that the recovery of $A$ baumannii in the hospitalized patient is an indicator of severe illness, with an associated mortality of approximately $30 \%(6)$.

One of the reasons that $A$ baumannii-associated disease is predominant among hospitalized patients is its inherent capacity to persist within healthcare facilities, thereby providing reservoirs for transmission and infection. This organism can readily colonize and survive on inanimate surfaces for extended periods of time. It is resistant to desiccation and disinfectants by forming biofilms on abiotic surfaces $(7,8)$; it develops multi-resistance to antibiotics and can acquire and disseminate antibiotic resistance by virtue of its extraordinary ability to accept or donate resistance plasmids (9-11) and the existence of the virulence factors poses a deleterious effect within the host. As a result, these aforementioned factors have made $A$ baumannii a successful pathogen, thus making the management of $A$ baumanii infections, a public health problem in many countries (12).

Over the last two decades, A baumannii has gained importance as a leading nosocomial pathogen, especially in critical care units. This organism, which was considered a low-virulence opportunistic pathogen, has turned into a multidrug resistant pathogen with increasing cases of morbidity and mortality. These attributes are alarming to healthcare providers worldwide. Despite the large number of studies and publications on the dynamics of this organism, more surveillance is needed, especially in Iran where there is a relative dearth of information on epidemiological distribution of its virulence factors and antimicrobial resistance dynamics. The aim of this study is to determine the prevalence, antimicrobial resistance and various resistance genes in A baumannii from human clinical samples in Iran using molecular techniques.

\section{MATERIAL AND METHODS}

\section{Sample collection}

In this cross-sectional study, 500 clinical specimens including: blood (98 samples), phlegm (141 samples), urine (92 samples), pus (134 samples) and CSF (35 samples) were collected from patients on admission at the Payambaran Hospital and Baqiyatallah Hospital in the city of Tehran, Iran, over a period of six months (from September 2012 to March 2013). These specimens were collected by a laboratory technician, properly labelled and then were transported immediately to the Microbiology laboratory.

\section{Isolation and identification of Acinetobacter baumannii}

I solation of $A$ baumannii was done using MacConkey and blood agar plate culture for all the specimens. The nonhaemolytic, opaque, creamy colonies on blood agar and nonlactose fermenting colonies on MacConkey agar were further sub-cultured on MacConkey agar and incubated for another 24 hours at $37^{\circ} \mathrm{C}$ to obtained pure colonies (13). The isolated organisms were identified based on colony morphology, microscopic study and various biochemical tests according to standard laboratory methods (13). Stock cultures were main- 
tained in both agar slant and 20\% sterile buffered glycerin and kept at $-70{ }^{\circ} \mathrm{C}$. The Acinetobacter isolates were tested for antibiotic resistance by Kirby-Bauer disk diffusion method [according to the Clinical and Laboratory Standards Institute guidelines] (14).

\section{Conventional polymerase chain reaction}

The reverse and forward primers, size of product as previously published used for the detection of $16 S-23 S$ ribosomal DNA, antimicrobial resistant genes in $A$ baumannii in the study are presented in Table 1. Polymerase chain reaction (temperature and volume) for detection of $16 S-23 S$ ribosomal DNA, antimicrobial resistance genes in A baumannii are also summarized in Table 2. The PCR amplified products $(10 \mu \mathrm{L})$ were subjected to electrophoresis in a $1.5 \%$ agarose gel in $1 \mathrm{X}$ TBE buffer at $80 \mathrm{~V}$ for 30 minutes, stained with solution of ethidium Bromide and examined under ultraviolet illumination (Uvitec, UK).

\section{Statistical analysis}

The prevalence analysis was computed in percentage and presented using descriptive statistics.

Table 1: Primers used for detection of virulence and antimicrobial resistant genes in Acinetobacter baumannii

\begin{tabular}{|c|c|c|c|c|}
\hline Gene & Primer name & Primer Sequence (5'-3') & Size of product (bp) & Reference \\
\hline Streptomycin & $\operatorname{aadAl}$ & $\begin{array}{l}\text { (F) TATCCAGCTAAGCGCGAACT } \\
\text { (R) ATTTGCCGACTACCTTGGTC }\end{array}$ & 447 & 15 \\
\hline Gentamycin & $a a c(3)-I V$ & $\begin{array}{l}\text { (F) CTTCAGGATGGCAAGTTGGT } \\
\text { (R) TCATCTCGTTCTCCGCTCAT }\end{array}$ & 286 & 15 \\
\hline Sulfonamide & sull & $\begin{array}{l}\text { (F) TTCGGCATTCTGAATCTCAC } \\
\text { (R) ATGATCTAACCCTCGGTCTC }\end{array}$ & 822 & 15 \\
\hline Beta-lactams & blaSHV & $\begin{array}{l}\text { (F) TCGCCTGTGTATTATCTCCC } \\
\text { (R) CGCAGATAAATCACCACAATG }\end{array}$ & 768 & 15 \\
\hline Beta-lactams & $C T X-M$ & $\begin{array}{l}\text { (F) TGGCCAGAACTGACAGGCAAA } \\
\text { (R) TTTCTCCTGAACGTGGCTGGC }\end{array}$ & 462 & 15 \\
\hline Chloramphenicol & cat1 & $\begin{array}{l}\text { (F) AGTTGCTCAATGTACCTATAACC } \\
\text { (R) TTGTAATTCATTAAGCATTCTGCC }\end{array}$ & 547 & 15 \\
\hline Chloramphenicol & $\mathrm{cmlA}$ & $\begin{array}{l}\text { (F) CCGCCACGGTGTTGTTGTTATC } \\
\text { (R) CACCTTGCCTGCCCATCATTAG }\end{array}$ & 698 & 15 \\
\hline Tetracycline & $\operatorname{tet}(A)$ & $\begin{array}{l}\text { (F) GGTTCACTCGAACGACGTCA } \\
\text { (R) CTGTCCGACAAGTTGCATGA }\end{array}$ & 577 & 15 \\
\hline Tetracycline & $\operatorname{tet}(B)$ & $\begin{array}{l}\text { (F) CCTCAGCTTCTCAACGCGTG } \\
\text { (R) GCACCTTGCTGATGACTCTT }\end{array}$ & 634 & 15 \\
\hline Trimethoprim & $d f r A 1$ & $\begin{array}{l}\text { (F) GGAGTGCCAAAGGTGAACAGC } \\
\text { (R) GAGGCGAAGTCTTGGGTAAAAAC }\end{array}$ & 367 & 15 \\
\hline Quinolones & $Q n r$ & $\begin{array}{l}\text { (F) GGGTATGGATATTATTGATAAAG } \\
\text { (R) CTAATCCGGCAGCACTATTTA }\end{array}$ & 670 & 15 \\
\hline Carbiniciline & $\begin{array}{l}\text { Imp-F } \\
\text { Imp-R }\end{array}$ & $\begin{array}{l}\text { 5'-GAATAGAATGGTTAACTCTC-3' } \\
\text { 5'-CCAAACCACTAGGTTATC-3' }\end{array}$ & 188 & 16 \\
\hline Carbiniciline & $\begin{array}{l}\text { Vim-F } \\
\text { Vim-R }\end{array}$ & $\begin{array}{l}\text { 5'-GTTTGGTCGCATATCGCAAC-3' } \\
\text { 5'-AATGCGCAGCACCAGGATAG-3', }\end{array}$ & 382 & 16 \\
\hline Carbiniciline & $\begin{array}{l}\text { Sim-F } \\
\text { Sim-R }\end{array}$ & $\begin{array}{l}\text { 5'-GTACAAGGGATTCGGCATCG-3' } \\
\text { 5'-GTACAAGGGATTCGGCATCG-3' }\end{array}$ & 569 & 16 \\
\hline Oxacillinases & $\begin{array}{l}\text { Oxa-51-like-F } \\
\text { Oxa-51-like-R }\end{array}$ & $\begin{array}{l}\text { 5'-TAATGCTTTGATCGGCCTTG-3 } \\
\text { 5'-TGGATTGCACTTCATCTTGG-3' }\end{array}$ & 353 & 16 \\
\hline Oxacillinases & $\begin{array}{l}\text { Oxa-23-like-F } \\
\text { Oxa-23-like-R }\end{array}$ & $\begin{array}{l}\text { 5'-GATCGGATTGGAGAACCAGA-3' } \\
\text { 5'-ATTTCTGACCGCATTTCCAT-3' }\end{array}$ & 501 & 16 \\
\hline Oxacillinases & $\begin{array}{l}\text { Oxa-24-like-F } \\
\text { Oxa-24-like-R }\end{array}$ & $\begin{array}{l}\text { 5'-GGTTAGTTGGCCCCCTTAAA-3', } \\
\text { 5'-AGTTGAGCGAAAAGGGGATT-3' }\end{array}$ & 246 & 16 \\
\hline Oxacillinases & $\begin{array}{l}\text { Oxa-58-like-F } \\
\text { Oxa-58-like-R }\end{array}$ & $\begin{array}{l}\text { 5'-AAGTATTGGGGCTTGTGCTG-3' } \\
\text { 5'-CCCCTCTGCGCTCTACATAC-3' }\end{array}$ & 599 & 16 \\
\hline A baumannii detection & $16 S-23 S$ ribosomal DNA & $\begin{array}{l}\text { (F) CATTATCACGGTAATTAGTG } \\
\text { (R) AGAGCACTGTGCACTTAAG }\end{array}$ & 208 & 17 \\
\hline
\end{tabular}


Table 2: Polymerase chain reaction conditions for detection of antimicrobial resistance genes in Acinetobacter baumannii

\begin{tabular}{|c|c|c|}
\hline Gene & PCR programme & PCR volume $(50 \mu \mathrm{L})$ \\
\hline $\begin{array}{l}\text { aadA1, aac(3)-IV, sul1, bla }{ }_{S H V}, \text { cat1, } \\
\text { cmlA, Imp }\end{array}$ & $\begin{array}{l}1 \text { cycle: } \\
94^{\circ \mathrm{C}} \\
32 \text { cycle: } \\
95^{\circ \mathrm{C}}-60 \mathrm{~min} . \\
55^{\circ \mathrm{C}}-70 \mathrm{~s} \\
72^{\circ \mathrm{C}}-2 \mathrm{~min} \\
1 \text { cycle: } \\
72^{\circ \mathrm{C}}\end{array}$ & $\begin{array}{l}5 \mu \mathrm{L} \text { PCR buffer } 10 \mathrm{X} \\
2.5 \mathrm{mM} \mathrm{Mgcl}_{2} \\
200 \mu \mathrm{M} \text { dNTP (Fermentas) } \\
0.5 \mu \mathrm{M} \text { of each primers F \& R } \\
2 \mathrm{U} \text { Taq DNA polymerase (Fermentas) } \\
3 \mu \mathrm{L} \text { DNA template }\end{array}$ \\
\hline tetA, tetB, dfrAl, bla $a_{C T X-M}$ & $\begin{array}{l}1 \text { cycle: } \\
94^{\circ \mathrm{C}} \\
32 \text { cycle: } \\
95^{\circ \mathrm{C}}-60 \mathrm{~min} . \\
55^{\circ \mathrm{C}} \\
72^{\circ \mathrm{C}}-70 \mathrm{~s} \\
1 \text { cycle: } \\
72^{\circ \mathrm{C}}\end{array}$ & $\begin{array}{l}5 \mu \mathrm{L} \text { PCR buffer } 10 \mathrm{X} \\
2.5 \mathrm{mM} \mathrm{Mgcl}_{2} \\
200 \mu \mathrm{M} \mathrm{dNTP} \text { (Fermentas) } \\
0.5 \mu \mathrm{M} \text { of each primers F \& R } \\
2 \mathrm{U} \text { Taq DNA polymerase (Fermentas) } \\
3 \mu \mathrm{L} \text { DNA template }\end{array}$ \\
\hline qnr, vim, sim & $\begin{array}{l}1 \text { cycle: } \\
94^{\circ \mathrm{C}}-6 \mathrm{~min} . \\
32 \text { cycle: } \\
95^{\circ \mathrm{C}}-60 \mathrm{~s} \\
55^{\circ \mathrm{C}}-70 \mathrm{~s} \\
72^{\circ \mathrm{C}}-70 \mathrm{~s} \\
1 \text { cycle: } \\
72^{\circ \mathrm{C}}\end{array}$ & $\begin{array}{l}5 \mu \mathrm{L} \text { PCR buffer } 10 \mathrm{X} \\
2.5 \mathrm{mM} \mathrm{Mgcl}_{2} \\
200 \mu \mathrm{M} \text { dNTP (Fermentas) } \\
0.5 \mu \mathrm{M} \text { of each primers F \& R } \\
2 \mathrm{U} \text { Taq DNA polymerase (Fermentas) } \\
3 \mu \mathrm{L} \text { DNA template }\end{array}$ \\
\hline $16 S-23 S$ ribosomal DNA & $\begin{array}{l}1 \text { cycle: } \\
94^{\circ \mathrm{C}}-6 \mathrm{~min} . \\
30 \text { cycle: } \\
95^{\circ \mathrm{C}}-60 \mathrm{~s} \\
58^{\circ \mathrm{C}}-60 \mathrm{~s} \\
72^{\circ \mathrm{C}}-40 \mathrm{~s} \\
11 \text { cycle: } \\
72^{\circ \mathrm{C}}\end{array}$ & $\begin{array}{l}5 \mu \mathrm{L} \text { PCR buffer } 10 \mathrm{X} \\
2 \mathrm{mM} \mathrm{Mgcl}_{2} \\
150 \mu \mathrm{M} \mathrm{dNTP} \mathrm{(Fermentas)} \\
1 \mu \mathrm{M} \text { of each primers F \& } \mathrm{R} \\
1 \mathrm{U} \text { Taq DNA polymerase (Fermentas) } \\
3 \mu \mathrm{L} \text { DNA template }\end{array}$ \\
\hline
\end{tabular}

PCR: polymerase chain reaction

\section{RESULTS}

During the study period, a total of 121 cultures of $A$ baumannii were detected out of 500 samples, representing $24.20 \%$ period prevalence. A baumannii was detected from all the sample groups, higher prevalence was observed in blood (43.87\%), phlegm $(24.11 \%)$ and urine $(23.11 \%)$ while relatively low prevalence was detected in CSF (17.14\%) and pus (11.94\%) [Table 3] (Fig.1).

Table 3: Prevalence of Acinetobacter baumannii strains isolated from human clinical samples

\begin{tabular}{lccc}
\hline $\begin{array}{l}\text { Clinical } \\
\text { samples }\end{array}$ & $\begin{array}{c}\text { No } \\
\text { samples }\end{array}$ & $\begin{array}{c}\text { No } \\
\text { A baumannii }\end{array}$ & Prevalence \\
\hline Blood & 98 & 43 & 43.87 \\
Phlegm & 141 & 34 & 24.11 \\
Urine & 92 & 22 & 23.91 \\
Pus & 134 & 16 & 11.94 \\
CSF & 35 & 6 & 17.14 \\
Total & 500 & 121 & 24.20 \\
\hline
\end{tabular}

No: number; CSF:cerebrospinal fluid

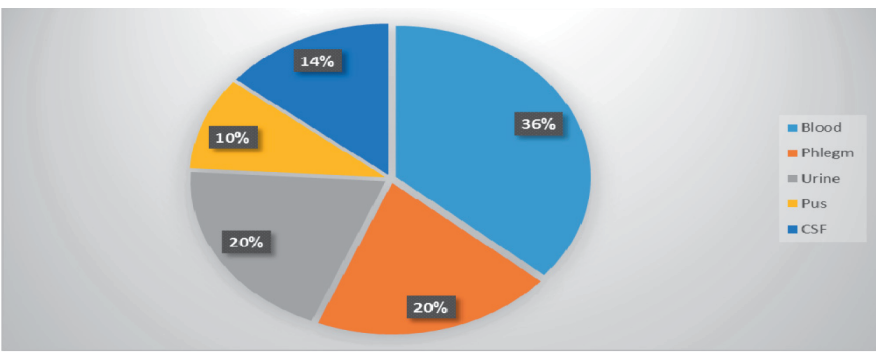

Fig. 1: Prevalence of Acinetobacter baumannii strains isolated from human clinical samples

Different antimicrobial resistance genes detected from this study were presented in Table 4a, Table $4 \mathrm{~b}$ and Fig 2; highest detection for resistant genes was observed for tetA (58.67\%), aac(3)-IV (56.19\%), sul1(55.37\%) and dfrAl (48.76\%).

Relatively low detection was observed for aad A1, blagenes (blaSHV, blaCTX-M, blaOXA-like, blaVIM, blaSIM and blaIMP), lowest detection was found for cat 1 and $\mathrm{cmlA}$ while no qnr gene was detected in this study. Antibiotic resistance profile of A baumannii is presented in Table 5a, Table 
Table 4a: Distribution of antibiotic resistance genes in Acinetobacter baumannii strains isolated from clinical samples in human

\begin{tabular}{|c|c|c|c|c|c|c|c|c|c|}
\hline Sample & $\operatorname{aad} A 1$ & $\operatorname{aac}(3)-I V$ & sul1 & $b^{b l a} a_{S H V}$ & bla $_{\text {CITM }}$ & tet $A$ & tetB & $d f r A 1$ & $q n r$ \\
\hline Blood (43) & 12 & 34 & 30 & 8 & 12 & 31 & 11 & 28 & 0 \\
\hline Phlegm (34) & 8 & 13 & 18 & 8 & 10 & 20 & 12 & 27 & 0 \\
\hline Urine (22) & 7 & 14 & 12 & 5 & 2 & 14 & 7 & 12 & 0 \\
\hline Pus (16) & 12 & 7 & 5 & 3 & 1 & 6 & 9 & 10 & - \\
\hline $\operatorname{CSF}(6)$ & 2 & - & 2 & _- & 3 & _- & 5 & 2 & 0 \\
\hline Total (121) & $41(33.88 \%)$ & $68(56.19 \%)$ & $67(55.37 \%)$ & $24(19.83 \%)$ & $28(23.14 \%)$ & $71(58.67 \%)$ & $44(36.36 \%)$ & $79(48.76 \%)$ & $0(0.00 \%)$ \\
\hline
\end{tabular}

CSF:cerebrospinal fluid

Table 4b: Distribution of antibiotic resistance genes in Acinetobacter baumannii strains isolated from clinical samples in human

\begin{tabular}{|c|c|c|c|c|c|c|c|c|c|}
\hline Sample & $\operatorname{Vim}$ & Sim & Oxa-51-like & Oxa-23-like & Oxa-24-like & Oxa-58-like & cat1 & $c m l A$ & $\operatorname{Imp}$ \\
\hline Blood (43) & 4 & 7 & 3 & - & 1 & - & - & - & 2 \\
\hline Phlegm (34) & 2 & - & 3 & 4 & 8 & 3 & - & - & 4 \\
\hline Urine (22) & 7 & 5 & 2 & 3 & 2 & 6 & 4 & 1 & 2 \\
\hline Pus (16) & 3 & 5 & - & 1 & - & 2 & 1 & 2 & 2 \\
\hline $\operatorname{CSF}(6)$ & - & - & 1 & - & 1 & 3 & - & - & - \\
\hline Total (121) & $16(13.22 \%)$ & $17(14.04 \%)$ & $9(7.43 \%)$ & $8(6.61 \%)$ & $13(10.74 \%)$ & $14(11.57 \%)$ & $5(4.13 \%)$ & $3(2.47 \%)$ & $10(8.26 \%)$ \\
\hline
\end{tabular}

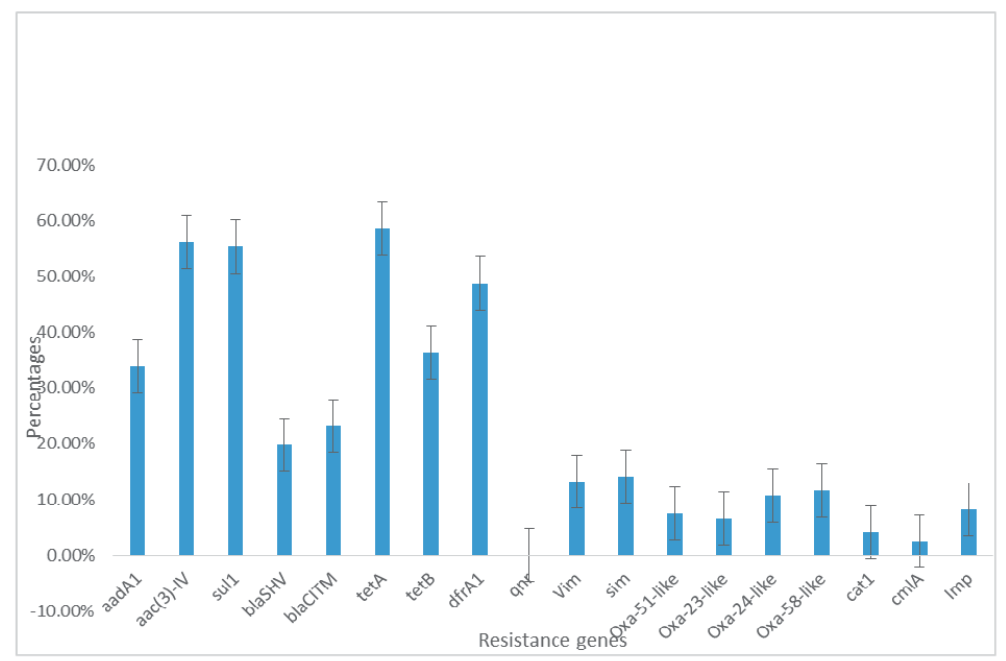

Fig. 2: Antibiotic resistance genes in Acinetobacter baumannii strains isolated from clinical samples in humans.

$5 \mathrm{~b}$ and Fig. 3; higher resistance was observed to tetracycline (90.90\%), trimethoprim (61.98\%), cotrimoxazole (51.23\%), followed by aminoglycosides such as tobramycin, streptomycin, gentamycin and amikacin (9.91-31.40\%). Relatively low resistance was observed to cephalosporins vis-a-vis cephalothin and ceftazidime (16.52-20.66\%), quinolones; ciprofloxacin and levofloxacin $(6.61-9.91 \%)$ and macrolides: erythromycin and azithromycin (8.26-14.04\%). While the lowest resistance was observed in: the carbapenems: imipenem and meropenem (3.3-5.78\%), chloramphenicol and nitrofurantoin.

\section{DISCUSSION}

A baumannii is one of the commonly isolated non-fermenting bacteria in human specimens, especially of nosocomial origin after Pseudomonas aeruginosa. Its infections are uncommon but, when they occur, it is usually associated with organ systems with high fluid content eg respiratory tract, CSF, peritoneal fluid and urinary tract (18-20). Just as observed in this study, A baumannii was detected from all sample groups from organs with fluid content including blood, urine and CSF. Jaggi et al (18) and Dash et al (21) have also reported the detection of this organism from pus, urine, sputum, blood and body fluids in tertiary hospitals in India. Colonization potentials as well as healthcare associated infection and outbreaks of 
Table 5a: Antibiotic resistance profiles in Acinetobacter baumannii strains isolated from clinical samples in humans

\begin{tabular}{|c|c|c|c|c|c|c|c|c|c|}
\hline Sample & streptomycin & gentamycin & Amikacin & tobramycin & co-trimoxazole & cephalotin & ceftazidime & tetracycline & trimetoprim \\
\hline Blood (43) & 11 & 19 & 8 & 7 & 29 & 12 & 8 & 41 & 28 \\
\hline Phlegm (34) & 7 & 10 & 3 & 2 & 17 & 9 & 2 & 30 & 26 \\
\hline Urine (22) & 6 & 7 & 4 & 3 & 11 & 2 & 7 & 20 & 12 \\
\hline Pus (16) & 12 & 2 & - & - & 4 & - & 3 & 15 & 9 \\
\hline CSF (6) & 2 & - & - & - & 1 & 2 & - & 4 & - \\
\hline Total (121) & $38(31.40 \%)$ & $38(31.40 \%)$ & $15(12.3 \%)$ & $12(9.91 \%)$ & $62(51.23 \%)$ & $25(20.66 \%)$ & $20(16.52 \%)$ & $110(90.90 \%)$ & 75 (61.98\%) \\
\hline
\end{tabular}

Table 5b: Antibiotic resistance profiles in Acinetobacter baumannii strains isolated from clinical samples in human

\begin{tabular}{|c|c|c|c|c|c|c|c|c|c|}
\hline Sample & ciprofloxacin & levofloxacin & imipenem & meropenem & cloramphenicol & nitrofurantoin & azithromycin & rifampin & erythromycin \\
\hline Blood (43) & 5 & - & 1 & 1 & - & - & 4 & 2 & 4 \\
\hline Phlegm (34) & 4 & 3 & 2 & - & - & - & 2 & 4 & 3 \\
\hline Urine (22) & 1 & 2 & 1 & 1 & 1 & 2 & 3 & 4 & 3 \\
\hline Pus (16) & - & 2 & 2 & - & 1 & - & 1 & - & 7 \\
\hline CSF (6) & 2 & 1 & 1 & - & - & - & - & - & - \\
\hline Total (121) & $12(9.91 \%)$ & $8(6.61 \%)$ & $7(5.78 \%)$ & $4(3.30 \%)$ & $2(1.65 \%)$ & $2(1.65 \%)$ & $10(8.26 \%)$ & $10(8.26 \%)$ & $17(14.04 \%)$ \\
\hline
\end{tabular}

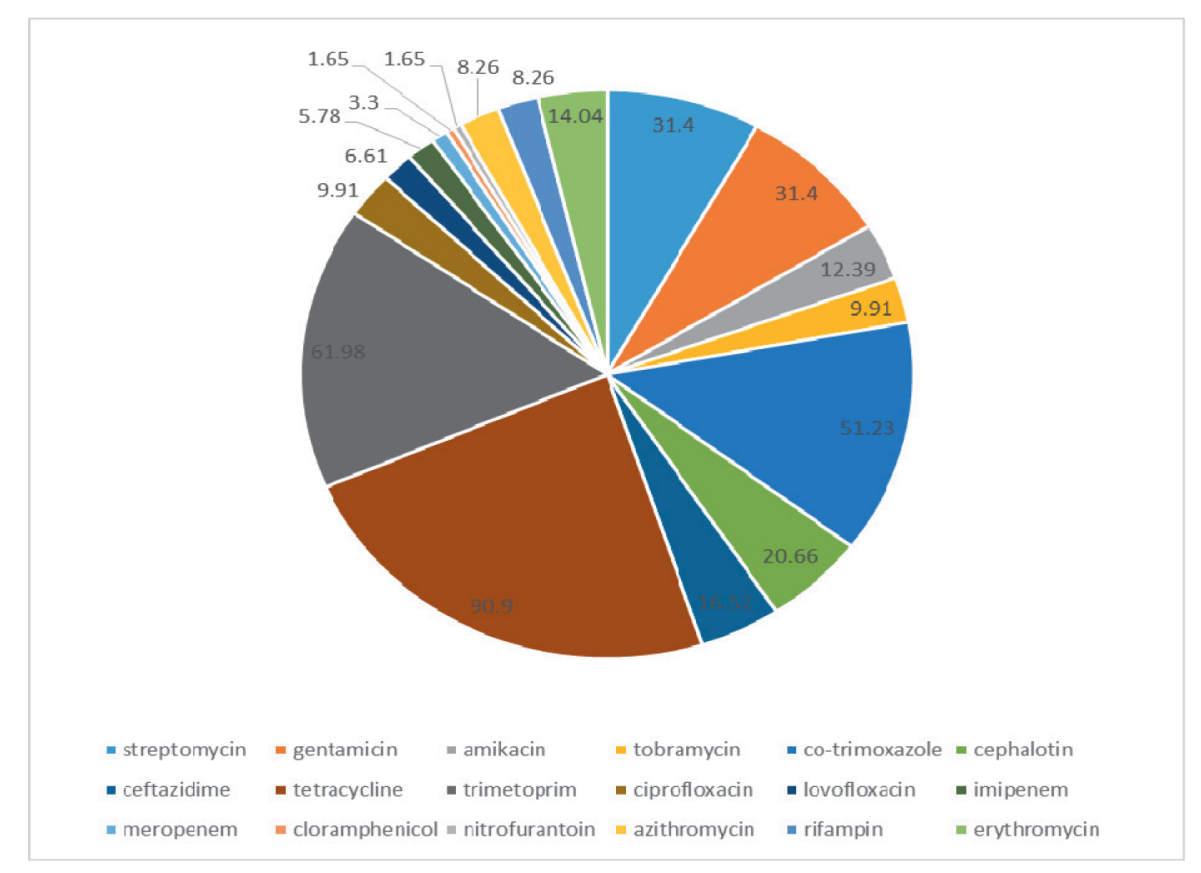

Fig. 3: Antibiotic resistance profiles in Acinetobacter baumannii strains isolated from clinical samples in human.

this organism have been reported (12). Detection of Acinetobacter from these samples may suggest either an on-going infection or colonization of organ sources with $A$ baumannii. However, detection of $A$ baumannii in blood samples suggests that Acinetobacter cannot exist as a colonizer in blood, it would have a higher pathogenic and septicaemic potential at this site. Since these patients are on hospital admission, there are possibilities that they may have acquired this organism from hospital environments such as surfaces and medical equipments and even beddings. Detection of this organism from the patients from the two hospitals may indicate or suggests that, these hospitals are contaminated with Acinetobacter with risk of nosocomial transmission and possibilities of future hospital outbreak.

One of the challenges with $A$ baumannii is its capacity to acquire myriads of antimicrobial-resistance genes rapidly, leading to multi-drug resistance, just as observed in this study. A baumannii detected in this study was resistant to all antibiotics tested in different proportion and were also found to carry different resistant genes to different classes of ant- 
ibiotics, thus, supporting the multi-drug resistant characteristic of A baumannii. Widespread use of antimicrobials within healthcare facilities have been considered to be a major factor in the emergence of antimicrobial resistance among Acinetobacter strains, in particular, the wide use of extendedspectrum cephalosporins and quinolones (22).

From this study, Acinetobacter baumannii resistant to tetracycline represented the highest antibiotic resistance recorded. Both tet $A$ and tet $B$ genes represented the most prevalent resistant genes observed in this study. This resistant pattern to tetracycline could be due to the indiscriminate use of this antibiotic either within the hospitals or the communities. The increased tetracycline resistance and tetracycline resistant genes recorded in the present study, support the fact that tet $A$ confers resistance to tetracycline only, while tet $B$ in addition to tetracycline confers resistance to minocycline $(23,24)$. This resistance to tetracycline and its derivatives is reported to be due to efflux pumps or ribosomal protective mechanisms (25). In this study, the prevalence of tet $A$ was observed to be higher than tet $B$, this is at variant to $66 \%$ and $13.6 \%$ reported for tet $B$ and tet $A$, respectively by Marti et al (26). Tetracycline resistant $A$ baumannii has been reported from Iran $(27,28)$, however, it has been reported that, in most clinical practices, use of tetracycline as therapy against $A$ baumannii infections is not common but high resistance to tetracycline is common among A baumannii isolates $(29,30)$ and the result of this study confirmed this claim.

The resistance among $A$ baumannii strains to $\beta$-lactam antibiotics although relatively lower, is of great concern. The $\beta$-lactams are broadly accepted for treatment; because of their availability, broad spectrum activities, reduced risk of side-effects, and importantly, their relatively low cost. Low resistance $(4-7 \%)$ to carbapenems ie imipenem and meropenem and close to $20 \%$ resistance to cephalosporin (cephalotin and ceftazidime) observed in the present study is lower than over 90\% reported to by Jaggi et al, in India (18), Japoni-Nejad et al, (27) and Safari et al (31) in I ran. Reduced resistance to cephalosporins and carbapenems may be due to non-use or judious use of these antibiotics in affected patients. This may also suggests that, carbapenems will be effective drugs in the management of Acinetobacter infections or in outbreaks in these hospitals. This finding has also been reported in most studies in Iran (32-34). The detection of $\beta$-lactamases such as blaSHV, blaCTXM, blaOXA-like (6.61-23.14\%) and Metallo-bêta lactamases (MBL) ie VIM, SIM and IMP (8.26-14.04\%) indicates and support the fact that A baumannii are ESBL and MBL producers.

Acinetobacter are known to produce a myriad of $\beta$-lactamases. The main mechanisms of resistance to extendedspectrum cephalosporins in A baumannii have been reported to be due to the over-expression of chromosomal cephalosporinases and plasmid-encoded Ambler class A, B, and $\mathrm{D} \beta$-lactamases (35). The blaOXA gene has been considered as a natural component of the species chromosome and has been used in identification of $A$ baumannii (36).
Previous report indicates blaOXA-51 genes are present in the vast majority of isolates of $A$ baumannii and may also be associated with resistance to carbapenems (35), however, in this study only $7.43 \%-11.57 \%$ of $A$ baumannii carried blaOXA genes. There has been some debate as to whether they are present in all isolates of this species (37).

Although, in this study, 4-7\% of $A$ baumannii are resistant to carbapenems, almost double of this organism (8.26$14.04 \%$ ) were observed to be a carriers of VIM, SIM and IMP; this may suggest the role of blaOXA genes in carbapenem resistance. Also, this may suggest the potentials of this organism to increase resistance to carbapenems in the near future in these hospitals. This increase in the number of MBLs in $\mathrm{A} \mathrm{bau-}$ mannii is a concerned development in the global emergence of MBL resistance to $\beta$-lactams.

In this study, tobramycin and amikacin showed better activities and higher sensitivities to A baumannii compared to streptomycin and gentamycin, A baumannii resistance to aminoglycosides is relatively low. Akers et al (38) have reported higher sensitivities of tobramycin to A baumannii. While Dauner et al (39) and Mostofi et al (40) reported reduced susceptibility to gentamycin against Acinetobacter. Amikacin showed higher sensitivity in this study compare to that reported by other studies (41). Susceptibility to aminoglycosides has changed a lot in recent years, gentamycin used to be an active agent against Acinetobacter infections, but now this organism has acquired resistance against this antibiotic. This resistance to aminoglycosides in A baumannii has been reported to be mediated principally by aminoglycoside-modifying enzymes [AMEs] (42). And the detection of $a a c(3)-I V$ and aadAl AMEs in this study corroborates this report. These AMEs have also been reported from different parts of the world including, Iran (34, 42, 43).

Quinolone resistance in A baumannii observed in this study is relatively low; this shows that quinolones have higher sensitivity to A baumannii. Non-detection of qnr gene in this study corroborates other reports worldwide (44-46). This plasmid mediated-quinolone resistance gene (PMQR) has not yet been reported in A baumannii. Acinetobacter baumannii resistance to quinolones has been reported to be due to modifications in the structure of DNA gyrase secondary to mutations in the quinolone resistance-determining regions of the gyrA and parC genes (47, 48). Higher resistance of $A$ baumannii to trimethoprim and co-trimoxazole $(>50 \%)$ observed in this study, have also been reported elsewhere $(49,50)$. Indiscriminate use of these antibiotics and higher detection of sull and $d f r A 1$ resistant genes in this organism against sulfonamides and trimethoprim may account for this. While chloramphenicol, nitrofurantoin, azithromycin, rifampin and erythromycin all showed higher sensitivities against $A$ baumannii, their therapeutic use in Acinetobacter infections is not widely reported and in most cases, their use maybe as adjunct therapy.

In conclusion, detection of Acinetobacter from different samples suggest either an on-going infection or colonization 
of organ sources with A baumannii. Resistance was observed in all antibiotics tested in different proportion and there were also different resistant genes to different class of antibiotics, thus, supporting the multi-drug resistant characteristic of A baumannii. Multi-drug resistant Acinetobacter infections are posing an increasing threat to the population in these communities. Carbapenems provide an effective option against infections caused by resistant $A$ baumannii.

\section{REFERENCES}

1. Koprnova J, Svetlansky I, Babel'a R, Bilikova E, Hanzen J, Zuscakova IJ et al. Prospective study of antibacterial susceptibility, risk factors and outcome of 157 episodes of Acinetobacter baumannii bacteremia in 1999 in Slovakia. Scand J Infect Dis 2001; 33: 891-5.

2. Maragakis LL, Cosgrove SE, Song X, Kim D, Rosenbaum P, Ciesla N et al. An outbreak of multidrug-resistant Acinetobacter baumannii associated with pulsatile lavage wound treatment. JAMA 2004; 292: 3006-11.

3. Doughari H, Ndakiedemi P, Human I, Benade S. The Ecology, Biology and Pathogenesis of Acinetobacter spp.: An Overview. Microbes Environ 2011; 26: 101-12.

4. Jeon BC, Jeong SH, Bae IK, Kwon SB, Lee K, Young D et al. Investigation of a nosocomial outbreak of imipenem-resistant Acinetobacter baumannii producing the OXA-23 _-lactamase in Korea. J Clin Microbiol 2005; 43: 2241-5.

5. Wilson SJ, Knipe CJ, Zieger MJ, Gabehart KM, Goodman JE, Volk HM et al. Direct costs of multidrug-resistant Acinetobacter baumannii in the burn unit of a public teaching hospital. Am J Infect Control 2004; 32: $342-4$.

6. Getchell-White SI, Donowitz LG, Groschel DH. The inanimate environment of an intensive care unit as a potential source of nosocomial bacteria: evidence for long survival of Acinetobacter calcoaceticus. Infect Control Hosp Epidemiol 1989; 10: 402-7.

7. Wendt C, Dietze B, Dietz E, Ruden H. Survival of Acinetobacter baumannii on dry surfaces. J Clin Microbiol 1997; 35: 1394-7.

8. Bergogne-Berezin E, Towner KJ. Acinetobacter spp. as nosocomial pathogens: microbiological, clinical, and epidemiological features. Clin Microbiol Rev 1996; 9: 148-65.

9. Smith MG, Gianoulis TA, Pukatzki S, Mekalanos JJ, Ornston LN, Gerstein $M$ et al. New insights into Acinetobacter baumannii pathogenesis revealed by high-density pyrosequencing and transposon mutagenesis. Genes Dev 2007; 21: 601-14.

10. Adams MD, Goglin K, Molyneaux N, Hujer KM, Lavender H, Jamison $\mathrm{JJ}$ et al. Comparative genome sequence analysis of multidrug-resistant Acinetobacter baumannii. J Bacteriol 2008; 190: 8053-64.

11. Landman D, Quale JM, Mayorga D, Adedeji A, Vangala K, Ravishankar $\mathrm{J}$ et al. Citywide clonal outbreak of multiresistant Acinetobacter baumannii and Pseudomonas aeruginosa in Brooklyn, NY: the preantibiotic era has returned. Arch Intern Med 2002; 162: 1515-20.

12. Peleg AY, Seifert H, Paterson DL. Acinetobacter baumannii: emergence of a successful pathogen. Clin Microbiol Rev 2008; 21: 538-82.

13. Forbes BA, Sahm DF, Weissfeld AS. Baily and Scott's diagnostic microbiology. 12thed. Mosby, Elsevire: 2007; 334-9.

14. Clinical and Laboratory Standards Institute. Performance standards for antimicrobial susceptibility testing: Nineteenth Informational Supplement. CLSI document M100-S19. Wayne; PA: USA. Clinical and Laboratory Standards Institute, 2009.

15. Momtaz H, Karimian A, Madani M, Safarpoor Dehkordi F, Ranjbar R, Sarshar M et al. Uropathogenic Escherichia coli in Iran: Serogroup distributions, virulence factors and antimicrobial resistance properties. Ann Clin Microbiol Antimicrob 2013; 12: 8.

16. Mostachio AK, van der Heidjen I, Rossi F, Levin AS, Costa SF. Multiplex PCR for rapid detection of genes encoding oxacillinases and metallo- $\beta$-lactamases in carbapenem-resistantAcinetobacter spp. J Med Microbiol 2009; 58: 1522-4.

17. Chiang MC, Kuo SC, Chen YC, Lee YT, Chen TL, Lee YT et al. Polymerase chain reaction assay for the detection of Acinetobacter bauman- nii in endotracheal aspirates from patients in the intensive care unit. J Microbiol Immunol Infect 2011; 44: 106-10.

18. Jaggi N, Sissodia P, Sharma L. Acinetobacter baumannii isolates in a tertiary care hospital: Antimicrobial resistance and clinical significance. J Microbiol Infect Dis 2012; 2: 57

19. Hemmatinezhad B, Ommi D, Hafshejani TT, Khamesipour F. Molecular detection and antimicrobial resistance of Pseudomonas aeruginosa from houseflies (Musca domestica) in Iran. J Venom Anim Toxins Incl Trop Dis 2015;21:18. doi:10.1186/s40409-015-0021-z.

20. Tajbakhsh E, Tajbakhsh S, Khamesipour F. Isolation and Molecular Detection of Gram Negative Bacteria Causing Urinary Tract Infection in Patients Referred to Shahrekord Hospitals, Iran. Iran Red Crescent Med J 2015;17(5):e24779. doi:10.5812/ircmj.17(5)2015.24779.

21. Dash M, Padhi S, Pattnaik S, Mohanty I, Misra P. Frequency, risk factors, and antibiogram of Acinetobacter species isolated from various clinical samples in a tertiary care hospital in Odisha, India. Avicenna J Med 2013; 3: 97-102.

22. Imperi F, Antunes LC, Blom J, Villa L, Iacono M, Visca P et al. The genomics of Acinetobacter baumannii: insights into genome plasticity, antimicrobial resistance and pathogenicity. IUBMB Life, Dec 2011; 63: $1068-74$.

23. Guardabassi L, Dijkshoorn L, Collard JM, Olsen JE, Dalsgaard A. Distribution and in vitro transfer of tetracycline resistance determinants in clinical and aquatic Acinetobacter strains. J Med Microbiol 2000; 49: 929-36.

24. Vila J, Marti S, Sanchez-Cespedes J. Porins, efflux pumps andmultidrug resistance in Acinetobacter baumannii. J Antimicrob Chemother 2007; 59: $1210-15$

25. Jamal W, Salama M, Dehrab N, Al Hashem G, Shahin M, Rotimi VO. Role of tigecycline in the control of a carbapenem-resistant Acinetobacter baumannii outbreak in an intensive care unit. J Hosp Infect 2009; 72: 234-42.

26. Martı' S, Ferna'ndez-Cuenca F, Pascual A, Ribera A, Rodríguez-Baño J, Bou $\mathrm{G}$ et al. Prevalence of the tetA and tetB genes as mechanisms of resistance to tetracycline and minocycline in Acinetobacter baumannii clinical isolates. Enferm Infecc Microbiol Clin 2006; 24: 77-80.

27. Bahador A, Taheri M, Pourakbari B, Hashemizadeh Z, Rostami H, Mansoori et al. Emergence of rifampicin, tigecycline, and colistin-resistant Acinetobacter baumannii in Iran; spreading of MDR strains of novel International Clone variants. Microb Drug Resist 2013; 19: 397-406.

28. Maleki MH, Sekawi Z, Soroush S, Azizi-Jalilian F, Asadollahi KH, Mahammadi $S$ et al. Phenotypic and genotypic characteristics of tetracycline resistant Acinetobacter baumannii isolates from nosocomial infections at Tehran hospitals. Iran J Basic Med Sci 2014; 17: 21-6.

29. Salazar De Vegas EZ, Nievesm B, Ruiz M, Ruíz J, Vila J, María A et al. Molecular epidemiology and characterization of resistance mechanisms to various antimicrobial agents in Acinetobacter baumannii isolated in Merida, Venezuela. Med Sci Monit 2007; 13: 89-94.

30. Japoni-Nejad A, Sofian M, Belkum A, Ghaznavi-Rad. Nosocomial outbreak of extensively and Pan Drug- Resistant Acinetobacter baumannii in Tertiary hospital in Central part of Iran. Jundishapur J Microbiol 2013; 6: e9892.

31. Safari M, Saidijam M, Bahador A, Jafari R, Alikhani MY. High prevalence of multidrug resistance and Metallo-beta-lactamase (M $\beta \mathrm{L}$ ) producing Acinetobacter baumannii isolated from patients in ICU wards, Hamadan, Iran. J Res Health Sci 2013; 13: 162-7.

32. Gaur A, Garg A, Prakash P, Anupurba S, Mohapatra TM. Observations on Carbapenem Resistance by Minimum Inhibitory Concentration in Nosocomial Isolates of Acinetobacter species: An Experience at a Tertiary Care Hospital in North India. J Health Popul Nutr 2008; 26: 183-8.

33. Hadadi A, Rasoulinejad M, Maleki Z, Yonesian M, Shirani A, Kourorian Z. Antimicrobial resistance pattern of Gram-negative bacilli of nosocomial origin at 2 university hospitals in Iran. Diagn Microbiol Infect Dis 2008; 60: 301-5.

34. Asadollahi K, Alizadeh E, Akbari M, Taherikalani M, Niakan M, Maleki A et al. The role of blaOXA-Like carbapenemase and thir insertion sequences (iss) in the induction of resistance againts carbapenem antibiotics among Acinetobacter baumanni isolates in Tehran hospitals. Roum Arch Microbiol Immunol 2011; 70: 153-8. 
35. Heritier C, Poirel L, Nordmann P. Cephalosporinase over- expression resulting from insertion of ISAba1 in Acinetobacter baumannii. Clin Microbiol Infect 2006; 12: 123-30.

36. Ramoul A, Hammami S, Dekhil M, Aimiri S, Slim A, Boutiba-Ben Boubaker I. Phenotypic and genotypic characterization of clinical multidrug resistant Acinetobacter baumannii from Algerian intensive care units. Afr J Microbiol Res 2013; 7: 868-74.

37. Brown S, Amyes SGB. OXA (beta)-lactamases in Acinetobacter: the story so far. J Antimicrob Chemother 2006; 57: 1-3.

38. Akers KS, Chaney C, Barsoumian A, Beckius M, Zera W, Yu X et al. Aminoglycoside resistance and susceptibility testing errors in Acinetobacter baumannii-calcoaceticus complex. J Clin Microbiol 2010; 48: $1132-8$.

39. Dauner G, May JR, Steele JCH. Assessing antibiotic therapy for Acinetobacter baumannii infections in an academic medical center. Eur J Clin Microbiol Infect Dis 2008; 27: 1021-4.

40. Mostofi S, Mirnejad R, Masjedian F. Multi-drug resistance in Acinetobacter baumannii strains isolated from clinical specimens from three hospitals in Tehran-Iran. Afr J Microbiol Res 2011; 5: 3579-82.

41. Irfan S, Idrees F, Mehraj V, Habib F, Adil S, Hasan R. Emergence of carbapenem resistant gram negative and vancomycin resistant gram positive organisms in bacteremic isolates of febrile neutropenic patients: A descriptive study. BMC Infect Dis 2008; 8: 80.
42. Nemec A, Dolzani L, Brisse S, van den Broek P, Dijkshoorn L. Diversity of aminoglycoside-resistance genes and their association with class 1 integrons among strains of pan-European Acinetobacter baumannii clones. J Med Microbiol 2004; 53:1233-40.

43. Noppe-Leclercq I, Wallet F, Haentjens S, Courcol R, Simonet M. PCR detection of aminoglycoside resistance genes: a rapid molecular typing method for Acinetobacter baumannii. Res Microbiol 1999; 150: 317-22.

44. Tran JH, Jacoby GA. Mechanism of plasmid-mediated quinolone resistance. Proc. Natl Acad Sci USA 2002; 99: 5638-42.

45. Nordmann P, Poirel L. Emergence of plasmid-mediated resistance to quinolones in Enterobacteriaceae. J Antimicrob Chemother 2005; 56: $463-9$.

46. Robicsek A, Strahilevitz J, Jacoby GA, Macielag M, Abbanat D, Park CH et al. Fluoroquinolone-modifying enzyme: a new adaptation of a common aminoglycoside acetyltransferase. Nat Med 2006; 12: 83-8.

47. Vila J, Ruiz J, Goni P, Jimenez de Anta T. Quinoloneresistance mutations in the topoisomerase IV parC gene of Acinetobacter baumannii. J Antimicrob Chemother 1997; 39: 757-62.

48. Seward RJ, Towner KJ. Molecular epidemiology of quinolones resistance in Acinetobacter spp. Clin Microbiol Infect 1998; 4: 248-54.

49. Banerjee G, Singh M, Goel N. Characterization of Acinetobacter from clinical isolates at Gandhi memorial and associated hospitals, Lucknow. J Commun Dis 2005; 37: 30-4.

50. Shali AK. Identification of multi-drug resistant genes in Acinetobacter baumannii in sulaimani city-kurdistan regional government of Iraq. Asian J Med Sci 2012; 4: 179-83. 